\title{
GINGIVAL EXTRAMEDULLARY PLASMACYTOMA IN DOG: A CYTOLOGICAL DIAGNOSIS
}

\author{
L. SOPHIA ${ }^{1}$, S. MONDAL ${ }^{* 1}$ AND G. SARKAR ${ }^{1}$ \\ ${ }^{1}$ Department of Veterinary Pathology, West Bengal University of Animal and Fishery Sciences, \\ 37, K. B. Sarani, Kolkata-700 037, West Bengal, India
}

\begin{abstract}
A 7 year old male Labrador Retriever was presented with a growth in the oral cavity, in Veterinary Clinical Complex (VCC), West Bengal University of Animal and Fishery Sciences (WBUAFS), Belgachia, Kolkata, for diagnosis. The growth was located on the left side of maxilla of the dog and was about $2-3 \mathrm{~cm}$ in diameter. The tissue sample was collected aseptically and routinely processed. The tumor was diagnosed as extramedullary plasmacytoma according to its morphological and microscopical characteristics. Extramedullary plasmacytoma in dog is rarely reported in India.
\end{abstract}

Key words: Cytology, Extramedullary plasmacytoma, Plasma cells, Soft tissue

Plasma cell proliferative disorder is characterized by increased numbers of plasma cells and its cytokines production in the system. Landgren et al. (2018) suggested that it leads to progressively more severe disease in terms of gammopathy in which a clone or multiple clones of anaplastic plasma cells sometimes along with other lymphocytes are over-produced and could be into the blood stream as in form of both the cells and its protein contents.

But plasmacytoma, considering an exception to this definition of plasma cell disorder, is a non-secretory type of multiple myeloma as it is the type in which no myeloma protein is detected in serum or urine having an evidence of clonal plasma cell-mediated tissue injury (Anderson et al., 2016). Basically plasmacytoma is a plasma cell disorder in which a plasma cell tumor grows within soft tissue or within the axial skeleton (Ding et al., 2019).

The solitary plasmacytoma of bone, having incidence of about 5\%, usually occurs in axial skeleton. Extramedullary plasmacytomas occur mostly (85\%) in upper respiratory tract but may occur in any soft tissue causing monoclonal gammopathies. The incidence of extramedullary plasmacytoma is much less than solitary plasmacytoma of bone and usually localized in submucosal tissues of upper aero-digestive tract. Both types of plasmacytomas are more prevalent among males as compared to females with a ratio of 2:1, in case of solitary plasmacytoma of bone and 3:1 for extramedullary plasmacytoma (Sher et al., 2010). Mostly found in dogs aged between 8-10 years (Cunha et al., 2017) and the most common areas of plasmacytoma are trachea, larynx, lips, oral cavity, stomach etc. (Moshref et al., 2007). In dogs, plasmacytoma can originate cutaneously or mucocutaneously (Pargass et al., 2017) but having highest incidence for cutaneous region as compared to other parts. They are solitary, smooth, elevated pink or red nodules of 1-2 cm diameter (Cunha et al., 2017).

We are reporting here a rare case of extramedullary plasmacytoma in the gingiva of a 7 year old male Labrador Retriever. A 7 year old male Labrador

\footnotetext{
"Corresponding Author
} 
Retriever was presented in the VCC clinics (WBUAFS) with a growth on the left side of maxilla over the canine tooth of about $2-3 \mathrm{~cm}$ in diameter (Fig. 1).

The direct impression smear of the growth was taken and stained with Leishman stain. The impression smear from the growth clearly met the malignancy criteria to be diagnosed as plasmacytoma with its' discrete neoplastic cell characterized by pleomorphism, anisocytosis, anisokariosis, marked cellular atypia, more basophilic cytoplasm and course chromatin (Fig. 2A\&B).

For histopathology, a biopsy sample collected aseptically was fixed in 10\% neutral buffered formalin. Formalin fixed tissues were processed further for histopathology. For tissue processing and staining routine procedure at the Department of Veterinary Pathology, WBUAFS were adopted. The slides were mounted with DPX and observed under simple light microscope (Fig. 2C).

Lymph node fine needle aspiration cytology (FNAC) was done to observe the idea of metastasis. Smear was prepared with aspirated fluid by crushed technique. Slides were then stained with Leishman stain (Fig. 3).

For haematological investigation $5 \mathrm{~mL}$ of blood was collected in collection vial with ethylene diamine tetraacetic acid (EDTA) as anticoagulant. After haematologic evaluation (Table 1) plasma was separated for biochemical estimation (Table 2).

Though there was no apparent discourse in the

Table 1. Report on haematological alteration

\begin{tabular}{lll}
\hline \multicolumn{1}{c}{ Test parameter } & Result & Reference value \\
\hline Haemoglobin(Hb) & $12.8 \mathrm{gm} / \mathrm{dL}$ & $12-18 \mathrm{gm} / \mathrm{dL}$ \\
Total leucocyte count(TLC) & $14,500 / \mathrm{cumm}$ & $6000-15,000 / \mathrm{cumm}$ \\
Differential leucocyte count & & \\
Neutrophil & $77 \%$ & $58-80 \%$ \\
Eosinophil & $02 \%$ & $2-8 \%$ \\
Basophil & $00 \%$ & $0-1 \%$ \\
Lymphocyte & $19 \%$ & $15-30 \%$ \\
Monocyte & $02 \%$ & $2-6 \%$ \\
\hline
\end{tabular}

Table 2. Report on Biochemical alteration

\begin{tabular}{lll}
\hline \multicolumn{1}{c}{ Test Parameter } & \multicolumn{1}{c}{ Result } & \multicolumn{1}{c}{ Reference value } \\
\hline Plasma glucose & $80 \mathrm{mg} / \mathrm{dL}$ & $70-150 \mathrm{mg} / \mathrm{dL}$ \\
BUN & $8.0 \mathrm{mg} / \mathrm{dL}$ & $7-25 \mathrm{mg} / \mathrm{dL}$ \\
Creatinine & $1.3 \mathrm{mg} / \mathrm{dL}$ & $0.5-1.5 \mathrm{mg} / \mathrm{dL}$ \\
Total protein & $6.4 \mathrm{gm} / \mathrm{dL}$ & $4.5-7.5 \mathrm{gm} / \mathrm{dL}$ \\
Albumin & $2.5 \mathrm{gm} / \mathrm{dL}$ & $2.5-4.0 \mathrm{gm} / \mathrm{dL}$ \\
Globulin & $3.9 \mathrm{gm} / \mathrm{dL}$ & $2.5-4.5 \mathrm{gm} / \mathrm{dL}$ \\
Albumin:Globulin & $1: 5$ & $0.6-1.5$ \\
Total bilirubin & $0.14 \mathrm{mg} / \mathrm{dL}$ & $0.01-0.5 \mathrm{mg} / \mathrm{dL}$ \\
Direct bilirubin & $0.11 \mathrm{mg} / \mathrm{dL}$ & $0.01-0.3 \mathrm{mg} / \mathrm{dL}$ \\
Indirect bilirubin & $0.03 \mathrm{mg} / \mathrm{dL}$ & $0.01-0.4 \mathrm{mg} / \mathrm{dL}$ \\
SGPT & $62 \mathrm{IU} / \mathrm{L}$ & $10-80 \mathrm{IU} / \mathrm{L}$ \\
SGOT & $55 \mathrm{IU} / \mathrm{L}$ & $10-75 \mathrm{IU} / \mathrm{L}$ \\
Alkaline phosphatase & $174 \mathrm{IU} / \mathrm{L}$ & $15-100 \mathrm{IU} / \mathrm{L}$ \\
\hline
\end{tabular}


Indian Journal of Animal Health, June, 2020

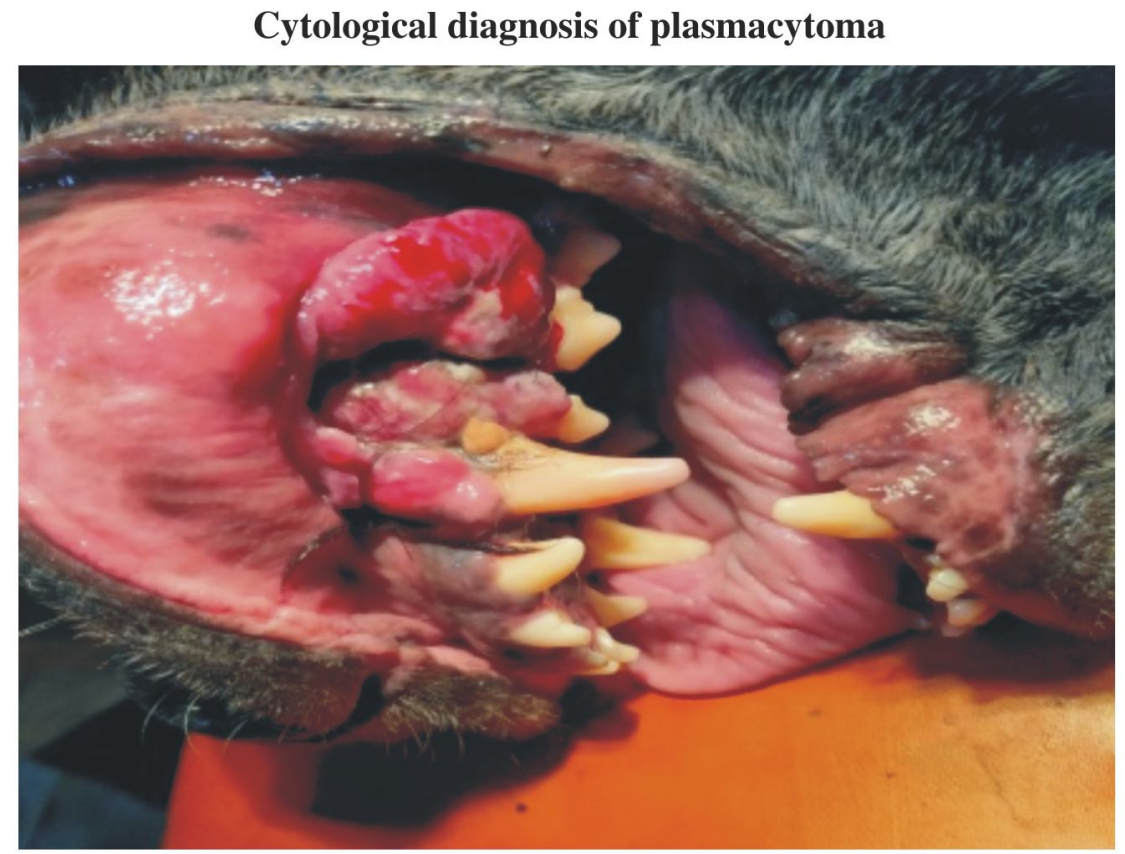

Fig 1. Tumourous growth on maxilla over the canine tooth
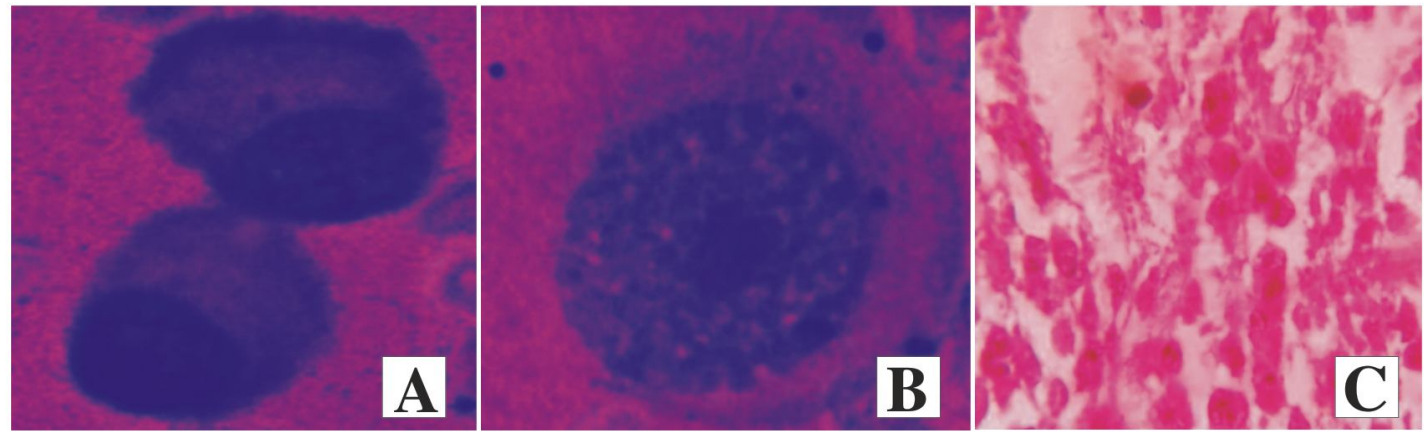

Fig 2. Direct impression smear of the tissue growth showing pleomorphic round cells with eccentric nucleus $[A, B]$ and histopathology showing large numbers of plasma cells $[\mathrm{C}]$. Maginifaction1000X
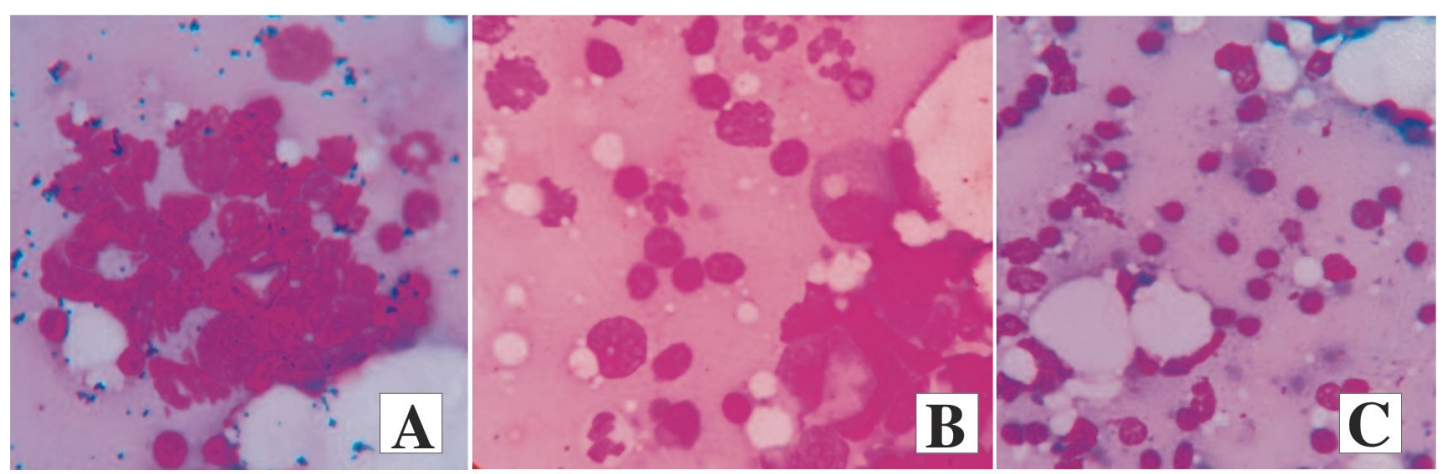

Fig 3. FNAC of prescapular lymph node showing multiple pleomorphic round cells with round to oval eccentrically placed nuclei along with lymphocytes and neutrophils. Maginifaction1000X [A,B\&C] 
haematobiochemical analysis, cytological examination revealed large number of round cells with round to oval eccentrically located nucleus. Metastasis of tumor was evident from the cytology of lymphnode and histopathology. The above results provided almost confirmatory diagnosis for extramedullary plasmacytoma (Kaler et al., 2012).

A plasma cell tumor of B-lymphocyte plasma cell lineage, having neoplastic cell origin in soft tissues or organs is termed as extramedullary plasmacytoma which is one of the rarest plasma cell tumors comprising $2.4 \%$ of all neoplasms in dogs (Cunha et al., 2017). These were frequently found in adult dog aged between 8 to 10 years (Pargass et al., 2017). The diagnosis of plasmacytoma could be made by cytology along with histopathology. Typical features as appreciated in the present case were discrete cells,

\section{REFERENCES}

Anderson KC, Alsina M, Atanackovic D, Biermann JS, Chandler JC et al., 2016. Clinical practice guidelines in oncology. J Natl Compr Canc Netw, 13(11): 1398-1435

Cangul IT, Wijnen M, Van Garderen E and Van den Ingh TS, 2002. Clinico-pathological aspects of canine cutaneous and mucocutaneous plasmacytomas. J Vet Med, 49(6): 307-312

Cunha RMC, Lavalle GE, Caires CET and Araujo RB, 2017. Electrochemotherapy treatment of oral extramedullary plasmacytoma of the tongue: A retrospective study of three dogs. Ciencia Rural, 47(12): e20170425

Ding W, Tan Y, Qian Y, Xue W, Wang Y et al., 2019. Primary plasmablastic plasmacytoma in the stomach of an immunocompetent adult: A case report. Medicine, 98(4): e14235

Kaler AK, Shankar A and Jena M, 2012. Extramedullary plasmacytoma of soft tissues and gingiva. Online J Health Allied Scs, 11(2): 9 eccentrically located nuclei with cellular atypia. Complete surgical excision was recommended as primary treatment for oral and cutaneous extramedullary plasmacytoma which might be often curative in case there was no metastasis (Cangul et al., 2002; Cunha et al., 2017; Pargass et al., 2017). But in metastasized condition the chances for recurrence of gingival extramedullary plasmacytoma were found to be highest. Prognosis was grave in the present case because of metastasis as evident in the lymphnode FNAC (Patricia et al., 2006).

The paper describes the oral extramedullary plasmacytoma of a dog. It also highlights the utility of cytology and histopathology in diagnosis of various canine neoplasms.

Conflict of interest: The authors declare that they have no competing interests.

Landgren O, Zeig-Owens R, Giricz O, Goldfarb D, Murata, K et al., 2018. Multiple myeloma and its precursor disease among firefighters exposed to the world trade center disaster. JAMA Oncol, 4(6): 821-827, doi: 10.1001/ jamaoncol.2018.0509

Moshref M, Abbass FM, Sargolzaei S and Nafarzadeh S, 2007, Extramedullary plasmacytoma of gingiva. Arch Iran Med, 10(1): 91-93

Pargass I, Bally A and Suepaul R, 2017. Oral plasmacytoma in dog. Vet Sci, 4(4): 68

Patricia AK, Catherine AP and Michael HG, 2006. Colorectal plasmacytomas: A retrospective study of nine dogs. J Am Anim Hosp Assoc, 42(1): $\quad$ 37-43

Sher T, Miller KC, Deeb G, Lee K and Chanan-Khan A, 2010. Plasma cell leukaemia and other aggressive plasma cell malignancies. $\mathrm{Br} \mathrm{J}$ Haematol, 150(4): 418-427,doi:10.1111/j.13652141.2010.08157.x

Received-24.03.2020, Accepted-12.05.2020, Published-01.06.2020 